\title{
Kanamış kafa içi anevrizması olan hastalarda endotelyal nitrik oksit sentaz (eNOS) geninin intron 4 (27 baz çifti tekrarı) ve promoter T786C polimorfizmi
}

Endothelial nitric oxide synthase gene intron 4 (27 base pair repeat) and promoter T786C polymorphism in patient with ruptured intracranial aneurysm.

Burçak Söylemez, Ünal Özüm*

Beyin ve Sinir Cerrahisi Kliniği (Dr. B. Söylemez), Erzincan Devlet Hastanesi, TR-24040 Erzincan, Beyin ve Sinir Cerrahisi Anabilim Dalı (Doç. Dr. Ü. Özüm), Cumhuriyet Üniversitesi Tıp Fakültesi, TR-58140 Sivas

Özet

Amaç. Nitrik Oksit (NO) sentezi, 3 izoformu bulunan nitrik oksit sentaz enzimi tarafindan düzenlenmektedir. Bunlar Endotelyal Nitrik Oksit Sentaz (eNOS), nöronal nitrik oksit sentaz (nNOS) ve indüklenebilir nitrik oksit sentaz (iNOS). ENOS, arter damar çapını düzenlemektedir, İşlevsel etkinliği dışında yapısal etkinliği de tespit edilmiş̧ir. Bu çalışmada eNOS genindeki iki polimorfizmle bir yapısal damar patolojisi olan kanamış kafa içi anevrizma varlığı arasındaki ilişki araştırıldı. Yöntem. Kanamış kafa içi anevrizması olan 43 hasta ve 46 sağlıklı bireyin DNA'larında eNOS geni intron 4 (27 baz çifti tekrarı) ve promoter T786C polimorfizmi jel elektroforez ve dizileme tekniği ile incelendi. Bulgular. CC homozigot genotip varlığı kanamış kafa içi anevrizması olan hasta grubunda anlamlı olarak yüksek olarak tespit edilmiştir $(\mathrm{p}<0,05)$. Hasta ve kontrol grupları arasında intron 4 (27 baz çifti tekrarı) açısından anlamlı fark tespit edilememiştir $(p>0,05)$. Sonuç. Homozigot T786C genotip varlı̆ğ çalışmaya aldığımız yöresel hasta grubunda kanamış kafa içi anevrizma varlığı açısından risk sebebi olarak görülmektedir. İntron 4 (27 baz çifti tekrarı) polimorfizminin varlığı ise risk teşkil etmemektedir.

Anahtar sözcükler: eNOS, nitrik oksit, anevrizma, SAK, polimorfizm

\begin{abstract}
Aim. Nitric oxide synthesis, 3-isoform in the nitric oxide synthase is regulated by the enzyme. These endothelial nitric oxide synthase (eNOS), neuronal nitric oxide synthase (nNOS) and inducible nitric oxide synthase (iNOS). eNOS, regulates the diameter of arterial vessels. Functional activity is outside the structural activity. In this study, eNOS gene, a structural vascular pathology of the two polymorphisms which compared the relationship between ruptured intracranial aneurysm. Method. Endothelial nitric oxide synthase gene intron 4 (27 base pair repeat) and promoter $\mathrm{T} 786 \mathrm{C}$ polymorphism of 43 patients with ruptured intracranial aneurysms and 46 control subjects were analysed by polymerase chain reaction and DNA sequencing method. Genotype distribution and allele frequencies of endothelial nitric oxide synthase gene polymorphism in patients with ruptured intracranial aneurysm and healthy subjects were compared. Result. CC genotype frequency was significantly higher in patients with ruptured intracranial aneurysm. It was also found that presence of eNOS $786 \mathrm{CC}$ genotype was significantly associated with risk of intracranial aneurysm rupture $(p<0.05)$. No significant difference was found between patient and control groups as to endothelial nitric oxide synthase gene intron 4 (27 base pair repeat) polymorphism ( $>0.05$ ). Conclusion. T786C polymorphism in endothelial nitric oxide synthase gene seems to be a possible risk factor for intracranial aneurysm rupture
\end{abstract}

Keywords: eNOS, Nitric oxide, intracranial aneurysm, SAH, polymorphism

Geliş tarihi/Received: 10 Temmuz 2013; Kabul tarihi/Accepted: 26 Temmuz 2013

*iletişim adresi:

Dr. Ünal Özüm, Beyin ve Sinir Cerrahisi Anabilim Dalı, Cumhuriyet Üniversitesi Tıp Fakültesi, TR-58140 Sivas. E-posta: sofamor@gmail.com 


\section{Giriş}

Kafa içi anevrizma patolojisinde pek çok görüş arasında, genetik bir takım faktörlerin üzerine eklenen edinsel faktörlerin rol oynadığı varsayımı, en çok kabul görenidir. $\mathrm{Bu}$ şekli ile anevrizmalar sonradan gelişen, zayıf duvarından dolayı her zaman için kanama potansiyeline sahip patolojik oluşumlar olarak dikkati çekmektedir.

Sakküler anevrizmaların duvarları, normal damar duvarında bulunan elastik membran ve kas duvarından yoksundur [1]. Bir yandan kanın kese içinde türbülans yapması, diğer taraftan da nabız vuruşlarının zayıf duvara kadar ulaşması, anevrizmaların genişlemesine neden olur. Spontan subaraknoid kanamaların \%73'ü bu şekilde gelişen kafa içi anevrizmaların yırtılması ile oluşmaktadır [2].

Nitrik oksit (NO), nitrik oksit sentaz (NOS) tarafindan L-Arjinin'in oksidasyonu ile sentez edilir. NOS'ın 3 izoformu tanımlanmıştır. Bunlardan iki tanesi, nöronal NOS (nNOS) ve endotelyal NOS (eNOS), bir diğeri ise indüklenebilir NOS (iNOS)'dur. NO, tespit edilmiş diğer fonksiyonunun yanında, esas olarak vasküler tonusu düzenler. Fizyolojik durumlarda NO doku hasarına yol açmaz, çünkü düzenli olarak oksihemoglobin tarafindan ortamdan temizlenir. Tam aksine, enfeksiöz ya da enflamatuar durumlarda endotoksinler ve inflamatuar sitokinler tarafindan indüklenen iNOS ise çok yüksek miktarlarda NO salınışına neden olur ve $\operatorname{artan}$ NO, yüksek miktarlarda serbest radikaller oluşturarak, konağın dokularında hasara yol açmasının yanı sıra hastalığın seyrini da değiştirir $[3,4]$

Endotelden düzenli olarak salınan NO, düzenli bir vazodilatasyon sağlayarak vasküler yatakta koruyucu etki gösterdiği iddia edilmektedir. Düzensiz salınan NO damar duvarında zayıflıklara ve hasara neden olarak anevrizma gelişimine yol açtı̆̆ da düşünülmektedir. Patolojik durumlarda aşırı NO salınışına neden olan iNOS'ın da bu şekilde anevrizma oluşumuna katkı yaptığı çalışmalarda iddia edilmiştir [5]. NO sentezinin düzensizliği, extrasellüler matriksin önemli bir yapı taş1 olan elastin proteininin miktarını değiştirmek sureti ile damar duvarının zayıflamasına neden olmaktadır $[1,6,7]$.

eNOS geni kromozom 7q35-36'da lokalize ve 21 kb'lık 26 ekson içerir, iNOS geni ise kromozom 17q11-12'de lokalize, 40 kb'llk 27 ekson içerir [8]. Bu genlerde meydana gelebilecek bir varyasyon NOS enziminde fonksiyon değişikliklerine yol açar ve devamında bir hastalık süreci gelişebilir [9]. DNA daki eNOS geni varyasyonları ile vasküler hastalıklar arasındaki ilişkiyi ortaya koymak için yapılmış pek çok araştırma mevcuttur. Bugüne kadar koroner arter hastalığı, miyokard enfaktüsü, hipertansion, strok ve renal hastalıklar gibi pek çok vasküler bozukluk eNOS geni polimorfizmi ile ilişkili bulunmuştur [10-15]. Ayrıca, aşırı NO salınışına neden olarak vasküler yatakta hasara neden olduğu gösterilen iNOS genindeki polimorfizimin de anevrizma patojenezinde önemli olabileceği düşünülmektedir [16]. Ancak araştırma sonuçları ırklar arasında değişkenlik gösterdiğinden özgün genetik varyantların sadece belli ırklara özgü olduğu düşünülebilir.

Şu ana kadarki bilgilerimiz 1şı̆̆ında, eNOS geni polimorfizmi ve iNOS geni polimorfizmi ile kafa içi anevrizmalar arasındaki ilişki henüz tam açıklanabilmiş değildir. Bu nedenle Türk toplumundaki kanamış kafa içi anevrizması olan hastalarda eNOS enzimine ait gendeki iki bölgede polimorfizmin olup olmadığını göstermek amacıyla, daha önce polimorfik olduğu gösterilen eNOS enzime ait iki gen bölgesindeki polimorfizmi araştıran, kontrollü bir çalışma yapılmıştır.

\section{Gereç ve yöntem}

Araştırma Cumhuriyet Üniversitesi Tip Fakültesi insan etik kurulunca 04/01/2010 tarihinde 01 no ile onaylanmıştır. Tüm hastalardan ve bilinci kapalı hastaların yakınlarından bilgilendirilmiş onam formu alınmıştır. 


\section{Denekler}

Hasta grubu Cumhuriyet Üniversitesi Tıp Fakültesi Beyin ve Sinir Cerrahisi Anabilim Dalında subaraknoid kanama tanısı ile yatan ve beyin anjiyografisi ile kafa içinde anevrizma gösterilmiş 43 bireyden oluşmuştur ( $28 \mathrm{kadın}, 15 \mathrm{erkek}$ ). Hastaların ortalama yaş $154,69 \pm 13,25$ (27-83)'dir. Kontrol grubu ise bir beyin damar hastalı̆̆ 1 olmayan, yaş ve cinsiyet yönünden hasta grubuna benzer sağliklı 46 bireyden oluşmuştur (26 kadın, 20 erkek). Kontrol grubundaki bireylerin ortalama yaşı 50,03 $\pm 15,49$ (20-75)'dir.

\section{DNA izolasyonu}

Genomik DNA, bireylerin EDTA'lı tüplere alınmış periferik venöz kanlarındaki lökositlerden DNA İzolasyon Kiti (Nukleo Spin Blood, Macherey-Nagel, ABD) kullanılarak elde edilmiştir.

\section{Polimeraz zincir reaksiyonu (PCR)}

İntron 4 (27 baz çifti tekrarı) polimorfizmi çalışması amacıyla 420 baz çiftli bölgenin amplifikasyonu için aşağıdaki primer çifti kullanıldı.

- 5'-CCTGGTTATCAGGCCCTATG-3'(forward),

- 5'-GTTTCTTAGGCTGCTCCTGCTACTGAC-3' (reverse).

$20 \mu$ l'lik son PCR karışımı $13 \mu$ l PCR mastermix (Fermantas, Kanada), $3 \mu l$ buffer her primerden $1 \mu \mathrm{l}$, ve $2 \mu \mathrm{l}$ DNA'dan oluşmaktayd. DNA, ilk denatürasyon $94^{\circ} \mathrm{C} 30$ saniye, ikinci denatürasyon $94^{\circ} \mathrm{C} 1$ dakika, bağlanma $61^{\circ} \mathrm{C} 1$ dakika, ilk sentez $72^{\circ} \mathrm{C} 40$ saniye, son sentez $72^{\circ} \mathrm{C} 10$ dakika'dan oluşan toplam 92 döngü ile amplifiye edildi. İşlem bittikten sonra, örnekler elektroforezde yürütülmek üzere $+4^{\circ} \mathrm{C}^{\prime}$ de saklanmıştır. PCR ürünleri \%2,5'luk agaroz jelde elektroforez yöntemi ile yürütülmüş ve ethidium bromür boyası ile boyanarak kontrolü yapılmıştır.

İçerisinde T876C varyant bölgesinde bulunan bölgenin amplifikasyonu için aşağıdaki primer çifti kullanıldı.

- 5'-TGAAGTGCCTGGAGAGTGC-3' (forvard)

- 5'-TGCAGGTTCTCTCCTTCACC-3' (reverse)

$20 \mu$ l'lik son PCR karışımı $13 \mu \mathrm{l}$ PCR matermix (Fermantas, Kanada), $3 \mu 1$ buffer her primerden $1 \mu \mathrm{l}$, ve $2 \mu \mathrm{l}$ DNA'dan oluşmaktaydı. DNA, ilk denatürasyon $94^{\circ} \mathrm{C} 30$ saniye, ikinci denatürasyon $94^{\circ} \mathrm{C} 1$ dakika, bağlanma $61^{\circ} \mathrm{C} 1$ dakika, ilk sentez $72^{\circ} \mathrm{C} 40$ saniye, son sentez $72^{\circ} \mathrm{C} 10$ dakika'dan oluşan toplam 92 döngü ile amplifiye edildi. İşlem bittikten sonra, örnekler elektroforezde yürütülmek üzere $+4^{\circ} \mathrm{C}$ 'de saklanmıştır. PCR ürünleri \%2,5'luk agaroz jelde elektroforez yöntemi ile yürütülmüş ve ethidium bromür boyası ile boyanarak kontrolü yapılmıştır.

\section{Genotipleme}

İntron 4 (27 baz çifti tekrarı) polimorfizmi için genotipleme elde edilen PCR ürünlerinin jel elektroforez sırasında elde edilen bantlarının moleküler uzunluklarına göre yapılmıştır. 420 bç moleküler uzunluğunda tek bant varsa homozigot (a/a) normal, 393 bç moleküler uzunluğunda tek bant varsa homozigot $4 \mathrm{~b} / \mathrm{b}$ varyant, her iki bç moleküler uzunluğunda bant mevcutsa heterozigot $4 \mathrm{a} / \mathrm{b}$ varyant olarak tanımland1. 4 rakamı, 4 . intron olduğunu belirtmektedir.

Promoter T786C polimorfizmi için DNA dizileme tekniği kullanılmış, 786 pozisyonda TT ise homozigot normal, $\mathrm{CC}$ ise homozigot varyant, TC ise heterozigot varyant olarak kabul edilmiştir. Normal homozigot TT dominant model olarak, anormal homozigot CC resesif model olarak tanımlanmıştır. 


\section{Istatistik}

Tüm veriler Windows için SPSS 10.0 (SPSS Inc, Chicago, IL, ABD) kullanılarak analiz edilmiş ve ortalama \pm standart kayma şeklinde kaydedilmiştir. Genotip dağılımlarının karşılaştırılmasında ve Hardy-Weinberg dengesinden kaymasının araştırmasında t testi ve ki-kare testi kullanıldı. \%95 güvenlik aralığında Odds oranı her bir normal ve anormal aleler ve genotip dağılımları için hesaplandı. Genotip değişiklikleri ile kanamış kafa içi anevrizma varlığı arasındaki ilişki için univariate regresyon analisi kullanıldı. İstatistiksel olarak anlamlı olan değişkenler için multivariate regresyon analizi yapıldı. $\mathrm{P}<0.05$ anlamlı olarak kabul edildi.

\section{Bulgular}

Hasta ve kontrol grubuna ait demografik veriler Tablo 1'de verilmiştir. Kontrol grubunda sigara içimi 1 lımlı şekilde yüksek çıkmıştır. Gruplar arasında sigara içimi yönünden anlamlı fark tespit edilmiştir $(\mathrm{p}<0,05)$. Yaş cinsiyet ve lipit yüksekliği açısından gruplar arasında anlamlı fark tepsi edilememiştir $(\mathrm{p}>0,05)$.

Tablo 1. Hasta ve kontrol gruplarının demografik ve klinik parametreler.

\begin{tabular}{llll}
\hline Değişkenler & Hasta $(\mathbf{n}=\mathbf{4 3})$ & Kontrol $(\mathbf{n}=\mathbf{4 6})$ & p değeri \\
\hline Yaş ( \pm SD) & $54,20 \pm 13,53$ & $50,03 \pm 15,49$ & 0,01 \\
Kadın (\%) & $28(65,1)$ & $26(56,5)$ & 0,407 \\
Sigara içimi (\%) & $31(72,1)$ & $41(89,1)$ & 0,041 \\
Lipit yüksekliği (\%) & $6(14,6)$ & $16(26,1)$ & 0,154 \\
\hline *SD: Standart sapma
\end{tabular}

\section{Promoter T786C polimorfizmi}

Tablo 2'de hasta ve kontrol gruplarına ait eNOS geni genotip ve alel dağılımları verilmiştir. Hasta grubundaki 43 kafa içi anevrizmalı bireyin eNOS ekson 7'deki T786C polimorfizmine göre eNOS TT genotip birey sayısı $18(\% 41,9)$, eNOS TC genotip birey sayıs1 $17(\% 39,5)$, eNOS CC genotip birey sayısı $8(\% 18,6)$ olarak saptanmıştır. 46 bireyden oluşan kontrol grubunda eNOS TT genotip birey sayısı $21(\% 45,7)$, eNOS TC genotip birey sayıs1 $23(\% 50)$ ve eNOS CC genotip birey say1s1 $2(\% 4,3)$ olarak bulunmuştur.

Tablo 2. Hasta ve kontrol grupları eNOS gen T786C polimorfizmi genotip dağılımı ve alel sıklığı.

\begin{tabular}{lllll}
\hline Genotip & Allel & Hasta $(\mathbf{n = 4 3})$ & Kontrol $(\mathbf{n = 4 6})$ & p değeri \\
\hline eNOS TT $(\%)$ & & $18(41,9)$ & $21(45,7)$ & 0,719 \\
eNOS TC (\%) & & $17(39,5)$ & $23(50)$ & 0,321 \\
eNOS CC (\%) & & $8(18,6)$ & $2(4,3)$ & 0,033 \\
& $786 \mathrm{~T}$ & $53(61)$ & $65(70)$ & 0,403 \\
\hline
\end{tabular}

eNOS: endotelyal nitrik oksid, TT: Timin-Timin normal homozigot, TC: Timin- Sitozin anormal heterozigot, CC: Sitozin-Sitozin anormal homozigot

Hasta ve kontrol grubunda ki bireylerin TT ve TC yönünden karşılaştırıldığında gruplar arası farklılık önemsiz bulunmuştur ( $>>0,005)$. Her iki grupta ki bireyler CC yönünden karşılaştırıldığında farklılık önemli bulunmuştur $(<0,005)$.

eNOS resesif model ile kafa içi anevrizmal SAK varlığı arasında anlamlı fark tespit edilirken (OR: 0,85, \%95 CI: 0,37-1,98, $\mathrm{p}=0,033$ ), dominant modelde bu ilişki tespit edilememiştir (OR: 5.02, \%95 CI: 1,03-25,2, p=0,719) (Tablo 3).

\section{Intron 4 (27 baz çifti tekrarı) polimorfizmi}

Hasta ve kontrol grubundaki tüm bireylerin genotipi $4 \mathrm{a} / \mathrm{a}$ tespit edilmiştir. Her iki grup arasında genotip açısından fark bulunamamıştır $(\mathrm{p}>0,05)$ 
Tablo 3. Tek ve çok değişkenli analizlere göre rüptüre intrakranial anevrizma eNOS gen polimorfizmi ile iliş kili odds oranları.

\begin{tabular}{lll}
\hline & OR (\%95 CI) & p değeri \\
\hline eNOS T786C dominant model (TT vs. TC+CC) & $0,85(0,37-1,98)$ & 0,719 \\
eNOS T786C resesif model (CC vs. TT+TC) & $5,02(1,03-25,2)$ & 0,033 \\
\hline
\end{tabular}

\section{Tartışma}

Son zamanlarda yapılan çalışmalarda, eNOS geni polimorfizmi, eNOS geninin işlevlerindeki bozukluk ile ilişkili bulunmuştur. eNOS genindeki bu tip işlevsel DNA değişikliklerin, eNOS'un salınışında ve enzimatik faaliyetinde değişikliklere neden oluğu ileri sürülmüştür $[17,18]$. eNOS enzimindeki miktar ve işlevsel değişiklikler de NO salınışını etkileyebilecektir. NO baskılanması ile deneysel olarak oluşturulan anevrizmaların gelişmesinin engellendiği gösterilmiştir [19, 20].

NO sentezleyen nitrik oksid enzimini kodlayan gen bölgesine ait polimorfizmlerle ile anevrizma varlığı, anevrizma yırtılması (anevrizmal subaraknoid kanama), anevrizma büyüklüğü, anevrizmal subaraknoid kanama sonrası vazospazm gelişimi arasındaki ilişki çeşitli çalışmalarla araştırılmış farklı bölgelere ait polimorfizmler ile bu durumlar arasında farklı toplumlarda farklı sonuçlar elde edilmiştir.

Khurana ve arkadaşlarının yaptığı, kafa içi anevrizmaların yırtılması ile ilgili çalışmada, eNOS T786C tek nükleotid polimorfizmini yırtılmış büyük ve küçük anevrizması olan hastalarda karşılaştırmış, hasta grubundaki tüm büyük anevrizması $(>10 \mathrm{~mm})$ olan hastalarda heterozigot polimorfizm varken küçük yırtılmış anevrizmalarda bu oranı \%41 olarak tespit etmiştir ve anevrizma büyüklüğü ile heterozigot polimorfizm arasında anlamlı bir ilişki tespit etmiştir [21]. Bununla birlikte Song ve arkadaşları ise Kore toplumunda T786C polimorfizminin hem anevrizma rüptürü, hem yırtılmış anevrizma boyutu hem de anevrizma subaraknoid kanama sonrası vazospazm gelişiminde katkısının olmadığını tespit etmişlerdir [22]. Aynı şekilde Akagawa ve arkadaşları da Japon ve Kore topluluklarını içeren ortak çalışmada Song ve arkadaşlarının sonuçlarına benzer sonuç elde etmişlerdir [23]. Bu iki çalışma ve benzeri diğer uzak doğu merkezli çalışmalar uzak doğu ülkelerinde T786C polimorfizminin konu edilen patolojilerde etkisinin olmadığ 1 kanaatini uyandırmıştır.

NOS enzimini kodlayan başka gen bölgeleri de araştırılmıştır. Örneğin Türk toplumunda homozigot G894T polimorfizmi anevrizmal subaraknoid kanamas1 olan hastalarda anlamlı şekilde yüksek çıkmış, kanamamış ile kanamış anevrizmaların karşılaştırıldığı bir başka çalışmada T786C, 4a-4b ve G864T polimorfizminin varlığ ile anevrizma yırtılması arasında anlamlı ilişki bulunmuştur [24].

Ayrıca T786C polimorfizmi birçok çalışmada bu polimorfizmin varlığının anevrizmal subaraknoid kanama sonrası gelişen vazospzm için yatkınlık meydana getirdiği gösterilmiştir [25].

Yaptığımız bu çalışmada, eNOS geninde sık karşılaşılan polimorfizmlerden olan, promoter bölge deki T786C ve intron 4'deki VNTR polimorfizmleri ile kafa içi anevrizmal subaraknoid kanama gelişimi arasında ilişki olup olmadığı araştırılmıştır. Bu amaçla hasta ve kontrol gruplarının bireylerinden elde edilen DNA'larda eNOS geninin polimorfizmlerine bakılarak her iki grup arasında alel ve genotip dağılımı açısından farklılık olup olmadığı incelenmiştir.

Hasta grubunda eNOS geni intron 4 VNTR polimorfizmi frekansı kafa içi anevrizma hastalarında ve kontrol grubunda anlamlı bir farklılık göstermemiştir. Kontrol grubundaki bireylerde de farklı genotipe rastlanmamıştır.

Homozigot T786C polimorfizm varlığ kanaması olan hasta grubunda anlamlı şekilde yüksek çıkmıştır. Promoter bölge RNA 
polimerazın ilk bağlandığı DNA dizeleridir. Transkripsiyonu yapılacak genin genellikle başında bulunur. mRNA'nın ilk bazının kodlandığı nukleotid dizelerinin bulunduğu yer transkripsiyonun başladığ 1 yerdir. Promoter bölgesi ise bu noktadan itibaren geriye doğru uzanan çok sayıda nukleotidden meydana gelmiştir. Polimorfizm sonucu artacak promoter aktivite NO sentezini artırırken azalmış promoter aktivite NO sentezini azaltacaktır. $\mathrm{Bu}$ bölgedeki çeşitli polimorfizmlerin nasıl bir etki gösterdiği bilinmemektedir. Artmış ve azalmış NO hangi yol ya da yolaklarla anevrizma oluşumu, anevrizmanın yırtılmas1, ya da anevrizmal subaraknoid kanama sonras1 vazospazm gelişimini de nasıl bir etki göstereceği açık değildir.

Artmış kafa içi anevrizma riskinden sorumlu genlerin bulunması, hastalıkların erken tanısına ve tedavisine olanak sağlayacaktır. eNOS'un genetik polimorfizmlerinin tedavideki etkilerini görmek daha uzun yıllar alacaktır. Ancak, endotele özgül ilaç tedavi yöntemleri yakın bir zamanda başlaması daha olasıdır. Şimdiye kadarki genetik çalışmaların çoğu karmaşık ve çok yönlü hastalıklara odaklanmıştır ve birçoğunda genetik etkiler tanımlanmıştır. eNOS genetik polimorfizmlerinin, endotelde etkili diğer genlerle (iNOS gibi) birlikte daha fazla araştırılması, hastalık süreçlerini ve mekanizmalarını daha iyi anlamamızı sağlayacaktır. Ayrıca, NOS genetik polimorfizmlerinin, değişmiş enzim veya hücre faaliyetini nasıl etkilediğinin aydınlatılması da faydalı olacaktır. Eğer enzim faaliyeti düşükse, belki de diyetle ek arjinin alımı gibi basit tedaviler faydalı olacaktır. Genetik ve gen tedavisi konusundaki çalışmalar ilerledikçe, seçici gen tedavileri kafa içi anevrizma gibi özgül durumlarda dahi kullanılır duruma gelecektir.

Tüm genetik araştırmalarda olduğu gibi NOS enzimini kodlayan gen bölgesine ait yapılan tüm çalışmalarda da çalışmaya dahil edilen deneklerin bulundukları toplumlara ait sonuçlar elde edilmektedir. Tüm insanlara yöneltilecek çıkarımların elde edilebilmesi için farklı toplumlardan deneklerin dahil edildiği çok merkezli çalışmalara ihtiyaç vardır.

\section{Kaynaklar}

1. Faraci FM, Brian JE. Nitric oxide and the cerebral circulation. Stroke 1994; 25: 692-703.

2. Menghini VV, Brown RD, Sicks JD, O'Fallon WM, Wieberg DO. Clinical manifettations and rates among patients with saccular intracranial aneurysms. Neurosurg 2001; 49: 251-8.

3. Brendt DS, Synder SH. Nitric oxide, a novel neuronal messenger. Neuron 1992; 8: 3-11.

4. Moncada S. The L-arginine-nitric oxide pathway. Acta Physiol Scand 1992; 145: 201-27.

5. Kataoka K, Taneda M, Asai T, Kinoshita A, Ito M, Kuroda R. Structural fragility and inflammatory response of ruptured cerebral aneurysms. A comparative study between ruptured and unruptured cerebral aneurysms. Stroke 1999; 30: 1396-401.

6. Kuhlecordt PJ, Gyurko R, Han F, Scherrer-Crosbie M, Aretz TH, Hajjar R, Picard MH, Huang PL. Accelerated atherosclerosis, aortic aneurysm formation, and ischemic hear disease in apolipoprotein endothellial nitric oxide synthase double-knockout mice. Circulation 2002; 104: 448-54.

7. Paik DC, Ramey WG, Dillon J. The nitrite/elastin reaction: implications for in vivo dejenerative effects. Connect Tissue Res 1997; 36: 241-51.

8. Marsden PA, Heng HH, Scherer SB, Sterward RJ, Hall AB, Shi XM. Structure and chromosomal localization of the human constitutive endothelial nitric oxide synthase gene. J Biol Chem 1993; 268: 17478-8.

9. Wattanapitayakul SK, Mihm MJ, Young AP, Bauer JA. Therapeutic implications of human endothelial nitric oxide synthase gene polymorphism. Trends Pharmacol Sci 2001; 22: 361-8.

10. Butler WE, Barker FG II, Cromwel RM. Patients with polycystic kidney disease would benefit from routine magnetic resonance angiographic screening for 
intracerebral aneurysms: a decision analysis. Neurosurgery 1996; 38: 506-16.

11. Gonzales-Gay MA. Inducible but not endothelial nitric oxide synthase polymorphism is associated with susceptibility to rheumatoid arthritis in northwest Spain. Rheumatology 2004; 43. 1182-5.

12. Hingorani AD. Polimorphisms in endothelial nitric oxide synthase and atherogenesis. Atherosclerosis 2000; 154: 521-6.

13. Kotani K,Shimomura T, Murakami F, Ikawa S, Kanaoka Y, Ohgi S, Adachi K, Nanba E. Allele frequency of human endothelial nitric oxide synthase gene polymorphism in abdominal aortic aneurysm. Intern Med 2000; 39: 537-9.

14. Kim J. U, Chang HK, Lee SS. Endothelial nitric oxide synthase gene polymorphisms in Behçet's disease and rheumatic diseases with vasculitis. Ann Rheum Dis 1998; 62: 1083-7.

15. Miyamoto Y. Saito Y, Kajiyama N, Yoshmura M, Shimasaki Y, Nakayama M, Kamitani S, Harada M. Endothelial nitric oxide synthase gene is positively associated with essential hypertension. Hypertension 1998; 32: 3-8.

16. Johanning JM, Armstrong PJ, Franklin DP. Nitric oxide in experimental aneurysm formation: early events and consequences of nitric oxide inhibition. Ann Vasc Surg 2002; 16: 65-72.

17. Moon J, Yoon S, Kim E. Lack of evidence for contribution of Glu298Asp (G894T) polimorphism of endothelial nitric oxide synthhase gene to plasma nitric oxide levels. Thrombosis Res 2002; 107: 129-34.

18. Tsukada T, Yokoyama K, Arai T, Takemoto F, Hara S, Yamada A. Evidence of association of the eNOS gene polymorphism with plasma NO metabolite levels in humans. Biochem Biophys Res Commun 1998; 245: 190-3.

19. Fukuda S, Hashimoto N, Naritomi H: Prevention of rat cerebral aneurysm formation by inhibitoin of nitric oxide synthase. Circulation 2000; 101: 2532-8.

20. Johanning JM, Franklin PD, Man DC. Inhibition of inductible nitric oxide synthase limits nitric oxide production and experimental aneurysm expansion. J Vasc Surg 2001; 33: 579-86.

21. Khurana VG, Sohni YR, Mangrum WI. Endothelial nitric oxide synthase T-786C single nucleotide polymorphism. A Putative genetic marker differentiating small versus large ruptured intracranial aneurysms. Stroke 2003; 2255-9.

22. Song M, Kim M, Kim T, Joo S, Park M, Kim B, Cho K. Endothelial nitric oxide gene T-786C polymorphism and subarachnoid hemorrhage in Korean population. J Korean Med Sci 2006; 21: 922-6.

23. Akogova H, Kasuya H, Onda H, Yoneyama T, Sasahara A, Kim CJ, Lee JC, Yang TK, Hori T, İnoue I. Influence of endothelial nitric oxide synthase T-786C single nucleotide polymorphism on aneurysm size. J Neurosurg 2005; 102: 6871.

24. Özüm Ü, Bolat N, Gül E, Özdemir Ö. Endothelial nitric oxide synthase gene (G894T) polymorphism as a possible risc factor in aneurysmal subarachnoid haemorrhage. Acta Neurochir 2008; 150: 57-62.

25. Ko N, Ranjendran P, Kim H, Rutkowski M, Pawlikowska L, Kwonk p, Higashida R, Lawton M, Smith W, Zaroff J, Young W. Endothelial nitric oxide synthase polymorphism (-786T $>C$ ) and increased risk of angiographic vasospazm after aneurysmal subarachnoid hemorrhage: Stroke 2008; 39: 1103-8. 